\title{
NEUROPROTECTIVE EFFECTS OF ANTIDOTES IN SOMAN-POISONED RATS
}

\author{
Jiři Kassa, Marie Koupilová
}

Purkyně Military Medical Academy, Hradec Králové: Department of Toxicology

Summary: 1. The neuroprotective effects of antidotes (atropine, obidoxime/atropine mixture, HI-6/atropine mixture) on rats poisoned with soman at a sublethal dose ( $48 \mu \mathrm{g} / \mathrm{kg}$ i.m.; $60 \%$ of $\mathrm{LD}_{50}$ value) were studied. The neurotoxicity was monitored using a functional observational battery (FOB) and an automatic measurement of motor activity. The neurotoxicity of soman was monitored at $24 \mathrm{~h}$ and $7 \mathrm{~d}$ following soman poisoning. 2 . The results indicate that atropine alone and the oxime HI-6 in combination with atropine seem to be effective antidotal treatment for the elimination of soman-induced neurotoxicity in the case of sublethal poisonings. 3. On the other hand, the combination of obidoxime with atropine appears to be practically ineffective in diminishing neurotoxic soman-induced symptoms. 4. Dealing with neuroprotective effects of antidotes, the oxime HI-6 in combination with atropine seems to be more suitable antidotal mixture than obidoxime in combination with atropine even in the case of sublethal poisoning with nerve agents.

Key words: Neurotoxicity; Soman; Behavioral screening; Obidoxime; Atropine; Rat

\section{Introduction}

The nerve agents are potent organophosphorus (OP) acetylcholinesterase (AChE, EC 3.1.1.7) inhibitors. An exposure to these agents causes a progression of toxic signs, including hypersecretions, fasciculations, tremor, convulsions, coma, respiratory distress and death $(16,21,23)$. These toxic effects are due to hyperactivity of the cholinergic system as a result of $\mathrm{AChE}$ inhibition and the subsequent increase in the amount of the neurotransmitter acetylcholine (ACh) at central and peripheral sites $(16,23)$. The antidotal treatment of OP agent-induced acute poisoning usually consists of anticholinergic drugs to antagonize the effects of $\mathrm{ACh}$ excess at cholinergic receptor sites and oximes to reactivate OP agent-inhibited AChE $(2,14)$.

Soman (pinacolyl methylphosphonofluoridate) is probably one of the most dangerous OP agents since its deleterious effects are especially difficult to counteract $(1,2)$. Soman seems to cause centrally mediated seizure activity that can rapidly progress to status epilepticus and contribute to the profound brain damage $(6,20)$. Thus, the exposure of experimental animals to soman in doses induced convulsions may result in irreversible lesions in the central nervous system that can be manifested as behavioral effects in convulsing survivors $(11,15,17,18)$. Unfortunately, the presently used antidotes, such as pralidoxime or obidoxime in combination with atropine, do not appear to ameliorate soman-induced toxic signs including centrally mediated seizure activity and motor convulsions $(1,13)$.

The aim of this study was to compare the neuroprotective effects of various antidotes in soman-poisoned rats. The soman-induced neurotoxic symptoms were determined using a functional observational battery (FOB), a non-invasive and relatively sensitive type of neurological examination in that a wide range of neurobiological functions is assessed, including measurements of sensory, motor and autonomic nervous functions.

\section{Methods}

Male albino Wistar rats weighing 180-230 g were purchased from Konárovice (Czech Republic). They were kept in an air-conditioned room and allowed to access to standard food and tap water ad libitum. The rats were divided into groups of eight animals. Handling of the experimental animals was done under the supervision of the Ethics Committee of the Medical Faculty of Charles University and the Military Medical Academy in Hradec Králové (Czech Republic).

Soman was obtained from Zemianské Kostolany (Slovak Republic) and was $98.5 \%$ pure. The oximes of 98.0\% purity were synthesized at the Department of Toxicology of the Military Medical Academy in Hradec Králové (Czech Republic). Their purities were analysed using HPLC. All other drugs and chemicals of analytical grade were obtained commercially and used without further purification. All substances were administered intramuscularly (i.m.) at a volume of $1 \mathrm{~mL} / \mathrm{kg}$ body weight (b.w.).

Soman was administered at a sublethal, convulsive dose (48 $\mu \mathrm{g} / \mathrm{kg}$ b.w. $-60 \%$ of $\mathrm{LD}_{50}$ ). One minute following soman injection, the rats were treated with atropine (21 
$\mathrm{mg} / \mathrm{kg}$ b.w.) alone or with atropine ( $21 \mathrm{mg} / \mathrm{kg}$ b.w.) in combination with the oxime HI-6 or obidoxime at equimolar doses $(100 \mu \mathrm{mol} / \mathrm{kg}$ b.w.). The neurotoxicity of soman was monitored using the FOB at 24 hours and 7 days following soman poisoning.

The FOB consists of 40 measurements of sensory, motor and autonomic nervous functions $(4,5,19,22)$ (Table 1$)$. The first evaluation was made when soman-poisoned rats were in the home cage. The observer evaluated each animal's posture, palpebral closure and gait and the presence or absence of convulsions was noted. Each rat was then removed from the home cage and briefly held in the hand. The presence or absence of spontaneous vocalization, piloerection and other fur and skin abnormalities as well as the irritability were noted too. Then, lacrimation and salivation were registered and scored. Other signs such as exophthalmus, crustiness around the eyes or emaciation were recorded too.

Then rats were placed on a flat surface which served as an open field. A timer was started for three minutes during which the frequency of rearing responses was recorded. At the same time, gait characteristics were noted and ranked, and arousal, tremor, convulsions and abnormal posture were evaluated. At the end of the third minute, the number of fecal boluses and urine pools on the absorbent pad were registered. Then, a reflex testing, that consists of recording each rat's response to the frontal approach of the blunt end of a pen, a touch of the pen to the posterior flank and an auditory clic stimulus, was used. The responsiveness to a pinch on the tail and the ability of pupils to constrict in response to light were then assessed. These measures were followed by a test for the aerial righting reflex, then by the measurements of forelimb and hindlimb grip strength, body weight, rectal temperature and finally hindlimb landing foot splay. The whole battery of tests required approximately 68 minutes per a rat.
Motor activity data were collected shortly after FOB testing, using an apparatus for testing of a spontaneous motor activity of laboratory animals (constructed in Purkyně Military Medical Academy, Hradec Králové, Czech Republic). The animals were placed for a short period (10 minutes) in the measuring cage and their movements (total horizontal activity, stereotypical activity, rearing, jumping, scratching, total vertical activity) were recorded.

Statistical analyses were performed on a PC with BMDP programme P7D: analysis of variance (ANOVA) and t-test with Bonfferoni's corrections.

\section{Results}

The results of the experiments related to the measurement of soman-induced neurotoxicity at $24 \mathrm{~h}$ and $7 \mathrm{~d}$ following soman poisoning are summarized in Table 2. The observation of neurotoxic signs indicated that some functional disorders of poisoned organisms outlasted at least 24 hours not only in untreated soman-poisoned rats but also in soman-poisoned rats treated with obidoxime and atropine. Some registered markers of neuronal damage of soman-poisoned rats are shown in Figures 1-5.

Diminished eating, including body weight loss, pronounced changes in piloerection and significantly decreased exploratory activity ( $\mathrm{p}<0.05$ ) was observed in untreated soman-poisoned rats as well as soman-poisoned rats treated with obidoxime/atropine mixture. Ptosis and the bloody secretion from the nose were observed in the case of untreated soman poisoning and poisoning treated with obidoxime/atropine mixture. On the other hand, practically all above mentioned neurotoxic signs were diminished when soman-poisoned animals were treated with atropine alone or atropine in combination with the oxime HI-6 (Table 2).

Tab. 1: Functional Observational Battery (FOB).

\begin{tabular}{|c|c|c|c|c|}
\hline \multicolumn{7}{|c|}{ Summary of Measures in the Functional Observational Battery } \\
\hline $\begin{array}{c}\text { Home-cage } \\
\text { and Handling Measures }\end{array}$ & Open Field & Other Measures & $\begin{array}{c}\text { Values in Absolute Units } \\
\text { Reaction }\end{array}$ & Other Measures \\
\hline Posture & Exploratory Activity & Pupil Response to Light & Approach Response & Landing Foot Splay (cm) \\
\hline Catch Difficulty & Urination & Righting Reflex & Touch Response & Forelimb Grip Strength (kg) \\
\hline Ease of Handling & Defecation & Fall from Vertical Position & Click Response & $\begin{array}{c}\text { Hindlimb Grip } \\
\text { Strength (kg) }\end{array}$ \\
\hline Muscular tonus & Clonic Convulsions & Damage of Respiration & Tail-pinch Response & $\begin{array}{c}\text { Forelimb and Hindlimg } \\
\text { Grip Strength (kg) }\end{array}$ \\
\hline Lacrimation & Tremor & & & Body Weight (g) \\
\hline Palpebral Closure & Tonic Convulsions & & & Rectal Temperature $\left({ }^{\circ} \mathrm{C}\right)$ \\
\hline Endo-Exophthalmus & Gait & & & Horizontal Activity \\
\hline Piloerection & Mobility & & & Vertical Activity \\
\hline Skin Abnormalities & Tensions & & & \\
\hline Salivation & Vocalizations & & & \\
\hline Secretion & Stereotypy & & & \\
\hline
\end{tabular}


The convulsions were not observed in any experimental group of animals at $24 \mathrm{~h}$ nor at $7 \mathrm{~d}$ following soman poisoning although they were manifested intensively shortly following soman administration. The significant alteration of gait $(\mathrm{p}<0.001)$ occured in untreated soman-poisoned animals and animals treated with obidoxime/atropine mixture at $24 \mathrm{~h}$ following soman poisoning (Table 2, Figure 1). These animals had awkward hindlimbs and their mobility was markedly diminished or totally eliminated $(p<0.001)$
(Table 2). Their posture was hump-backed or they were lying on their abdomen without stretched limbs (Table 2). Their reaction to sensory stimulus, including tail-pinch response, was markedly affected ( $p<0.05)$ (Table 2, Figure 2) and their rectal temperature was reduced at $24 \mathrm{~h}$ following soman poisoning $(\mathrm{p}<0.01)$ (Table 2). Their forelimb and hindlimb grip strength as well as the distance between hindpaws after a jump were significantly diminished $(\mathrm{p}<0.001)$ (Table 2, Figure 3 ) and their spontaneous horizontal as well

Tab. 2: The values of soman-induced neurotoxic markers measured by FOB (No 1 - \% of control values, No 2-32 - scored values, No 33-40 - values in absolute units). Statistical significance: ${ }^{*} \mathrm{p}<0.05,{ }^{* *} \mathrm{p}<0.01,{ }^{* *} \mathrm{p}<0.001$. X - arithmetical mean of values.

\begin{tabular}{|c|c|c|c|c|c|c|c|c|c|c|c|}
\hline \multirow{3}{*}{ 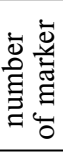 } & marker & \multicolumn{2}{|c|}{ controls } & \multicolumn{2}{|c|}{ soman } & \multicolumn{2}{|c|}{ soman+atropine } & \multicolumn{2}{|c|}{$\begin{array}{c}\text { soman+atropine } \\
+ \text { HI- } 6\end{array}$} & \multicolumn{2}{|c|}{$\begin{array}{c}\text { soman+atropine } \\
\text { +obidoxime }\end{array}$} \\
\hline & & 24 hours & 7 days & 24 hours & 7 days & 24 hour & 7 days & 24 hours & 7 days & 24 hours & 7 days \\
\hline & & \multicolumn{2}{|c|}{$x$} & \multicolumn{2}{|c|}{$x$} & \multicolumn{2}{|r|}{$x$} & \multicolumn{2}{|c|}{$x$} & \multicolumn{2}{|l|}{$x$} \\
\hline 1 & food & $100 \%$ & $100 \%$ & $10 \%$ & $100 \%$ & $100 \%$ & $100 \%$ & $79 \%$ & $100 \%$ & $86 \%$ & $100 \%$ \\
\hline 2 & posture & 3,00 & 2,12 & 3,50 & 3,14 & 3,25 & 2,75 & 3,12 & 2,25 & 4,00 & 2,60 \\
\hline 3 & catch difficulty & 1,00 & 1,00 & 1,50 & 1,08 & 1,00 & 1,00 & 1,00 & 1,00 & $2,00 * * *$ & 1,00 \\
\hline 4 & ease of handling & 1,00 & 1,00 & 1,50 & 1,00 & 1,00 & 1,00 & 1,00 & 1,00 & $1,83 * * *$ & 1,00 \\
\hline 5 & muscular tonus & 1,00 & 1,00 & 1,62 & 1,00 & 1,00 & 1,00 & 1,00 & 1,00 & $2,00 * * *$ & 1,00 \\
\hline 6 & lacrimation & 1,00 & 1,00 & 1,25 & 1,00 & 1,00 & 1,00 & 1,00 & 1,00 & $2,00 * * *$ & 1,00 \\
\hline 7 & palpebral closure & 1,00 & 1,00 & $2,25 * * *$ & 1,28 & 1,00 & 1,00 & 1,00 & 1,00 & 1,00 & 1,00 \\
\hline 8 & endo-exophthalmus & 1,00 & 1,00 & $1,75^{*}$ & 1,43 & 1,00 & 1,00 & 1,00 & 1,00 & 1,00 & 1,00 \\
\hline 9 & piloerection & 1,00 & 1,00 & $6,25 * * *$ & 3,00 & 1,00 & 1,00 & 1,00 & 1,00 & $8,00 * * *$ & 2,40 \\
\hline 10 & skin abnormalities & 1,00 & 1,00 & 1,25 & 1,00 & 1,00 & 1,00 & 1,00 & 1,00 & 1,00 & 1,00 \\
\hline 11 & \begin{tabular}{|l|} 
salivation \\
\end{tabular} & 1,00 & 1,00 & 1,00 & 1,00 & 1,00 & 1,00 & 1,00 & 1,00 & $3,00 * * *$ & 1,00 \\
\hline 12 & secretion & 1,00 & 1,00 & $2,62 * *$ & 1,42 & 1,75 & 1,00 & 1,00 & 1,00 & $4,00 * * *$ & 1,00 \\
\hline 13 & exploratory activity & 8,12 & 5,25 & $1,37 *$ & 2,42 & 7,12 & 6,12 & 11,87 & 5,37 & $0,66^{* *}$ & 7,20 \\
\hline 14 & urination & 1,75 & 1,62 & $0,12^{*}$ & 1,57 & 2,87 & 3,50 & 3,25 & 6,12 & $8,66 * * *$ & 1,80 \\
\hline 15 & defecation & 2,37 & 0,50 & 0,50 & 2,42 & 1,75 & 1,87 & 0,00 & 1,75 & 2,83 & 3,80 \\
\hline 16 & clonic convulsions & 1,00 & 1,00 & 1,50 & 1,00 & 1,00 & 1,00 & 1,25 & 1,00 & 1,50 & 1,00 \\
\hline 17 & tonic convulsions & 1,00 & 1,00 & 2,37 & 1,00 & 1,50 & 1,00 & 1,00 & 1,00 & 1,16 & 1,00 \\
\hline 18 & \begin{tabular}{|l|} 
gait \\
\end{tabular} & 1,00 & 1,00 & $5,12 * * *$ & 2,14 & 1,25 & 1,00 & 1,25 & 1,00 & $4,33 * * *$ & 1,00 \\
\hline 19 & gait score & 1,00 & 1,00 & $2,87 * * *$ & 1,57 & 1,00 & 1,00 & 1,00 & 1,00 & $3,66 * * *$ & 1,00 \\
\hline 20 & mobility score & 1,00 & 1,00 & $2,87 * * *$ & 2,42 & 1,00 & 1,37 & 1,00 & 1,00 & $3,33 * * *$ & 1,00 \\
\hline 21 & activity & 1,00 & 1,00 & $2,75 * * *$ & 2,57 & 1,00 & 1,37 & 1,62 & 2,62 & $2,00 *$ & 1,20 \\
\hline 22 & tension & 1,00 & 1,00 & $2,00 * * *$ & 1,00 & 1,00 & 1,00 & 1,00 & 1,00 & 1,00 & 1,00 \\
\hline 23 & stereotype & 1,00 & 1,00 & $1,25 * * *$ & $2,14 * * *$ & 1,00 & 1,00 & 1,00 & 1,00 & 1,00 & 1,00 \\
\hline 24 & approach response & 1,50 & 1,25 & 2,00 & 1,14 & 1,25 & 1,12 & 1,00 & 1,12 & $2,66^{*}$ & 1,40 \\
\hline 25 & touch response & 1,62 & 1,75 & 2,12 & 2,00 & 1,87 & 1,75 & 2,00 & 2,00 & 2,00 & 2,00 \\
\hline 26 & \begin{tabular}{|l|} 
click response \\
\end{tabular} & 1,62 & 1,00 & 2,75 & 1,28 & 2,50 & $2,87 *$ & 1,75 & 2,12 & 3,16 & 1,60 \\
\hline 27 & tail-pinch response & 1,00 & 1,25 & $2,25 *$ & 1,14 & 1,00 & 1,12 & 1,37 & 1,00 & $2,33^{*}$ & 1,00 \\
\hline 28 & pupil size & 1,00 & 1,00 & 1,00 & 1,00 & 1,00 & 1,00 & 1,00 & 1,00 & $3,00 * *$ & 1,40 \\
\hline 29 & pupil response & 1,00 & 1,00 & 1,00 & $2,42 *$ & 1,00 & 1,25 & 1,00 & 1,00 & $3,00^{* *}$ & 1,00 \\
\hline 30 & righting reflex & 1,00 & 1,00 & 1,62 & 1,00 & 1,00 & 1,00 & 1,00 & 1,00 & 2,33 & 1,00 \\
\hline 31 & fall from vertical position & 1,00 & 1,00 & 1,37 & 1,00 & 1,00 & 1,00 & 1,00 & 1,00 & 2,00 & 1,00 \\
\hline 32 & damage of respiration & 1,00 & 1,00 & 2,00 & 1,00 & 1,25 & 1,00 & 1,00 & 1,00 & $3,66 * * *$ & 1,00 \\
\hline 33 & landing foot splay $(\mathrm{cm})$ & 88,25 & 95,75 & $55,93^{*}$ & $74,14^{*}$ & 83,06 & 81,75 & 88,06 & 88,37 & $65,00^{*}$ & $76,20^{*}$ \\
\hline 34 & forelimb grip strenght $(\mathrm{kg})$ & 6,83 & 6,26 & $2,86 * * *$ & 4,92 & 6,16 & 5,61 & 7,20 & 6,51 & $3,63^{*}$ & 7,86 \\
\hline 35 & hindlimb grip strength $(\mathrm{kg})$ & 3,29 & 3,71 & $1,11 * *$ & 3,18 & 2,18 & 3,05 & 2,28 & 3,62 & $0,78 * * *$ & 2,80 \\
\hline 36 & grip stren.of for and hindlimb & 19,26 & 18,56 & $5,90 * * *$ & 15,65 & 14,23 & 17,71 & 13,58 & 19,92 & $6,61 * * *$ & 16,96 \\
\hline 37 & body weight $(\mathrm{g})$ & 190,37 & 205,87 & $65,5^{*}$ & 181,57 & 200,37 & 206,37 & 196,00 & 219,75 & $160,66^{*}$ & 186,60 \\
\hline 38 & rectal temperature $\left({ }^{\circ} \mathrm{C}\right)$ & 38,08 & 37,80 & $36,22 * *$ & 35,94 & 37,65 & 37,41 & 37,62 & 37,78 & $34,08 * * *$ & 37,62 \\
\hline 39 & activity horizont (No/10 min) & 522,75 & 384,00 & $176,50 * * *$ & 380,14 & 469,50 & 479,12 & 334,62 & 341,25 & $62,33 * * *$ & 409,40 \\
\hline 40 & activity vertical $(\mathrm{No} / 10 \mathrm{~min})$ & 178,87 & 91,12 & $58,50^{*}$ & 110,28 & 146,87 & 181,87 & 96,12 & 112,12 & $2,33 * * *$ & 105,60 \\
\hline
\end{tabular}


Fig. 1: The neuroprotective effect of antidotes on soman-induced alteration of the gait at $24 \mathrm{~h}$ and $7 \mathrm{~d}$ following soman challenge. $\mathrm{C}$ - control values, treatment 1 - atropine alone, treatment 2 - atropine + the oxime HI-6, treatment 3 - atropine + obidoxime.

Gait

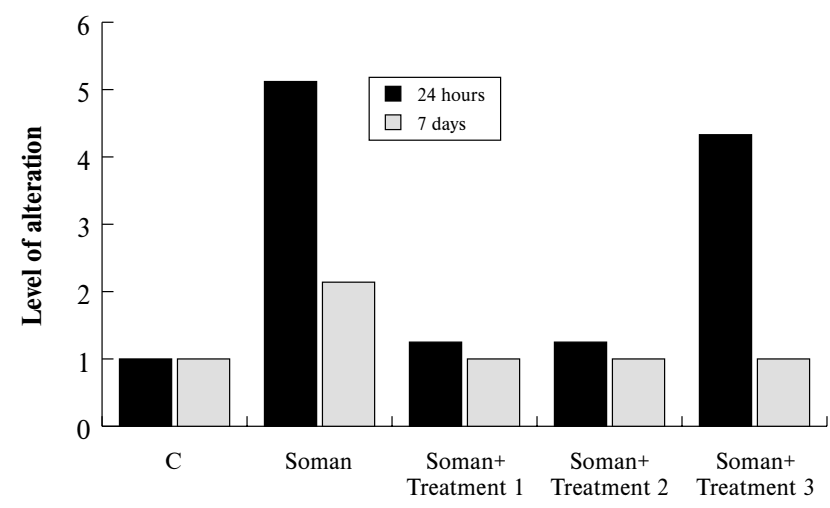

Fig. 2: The neuroprotective effect of antidotes on soman-induced latency of the tail-pinch response at $24 \mathrm{~h}$ and $7 \mathrm{~d}$ following soman challenge. For symbols - see Fig. 1.

Tail-pinch response

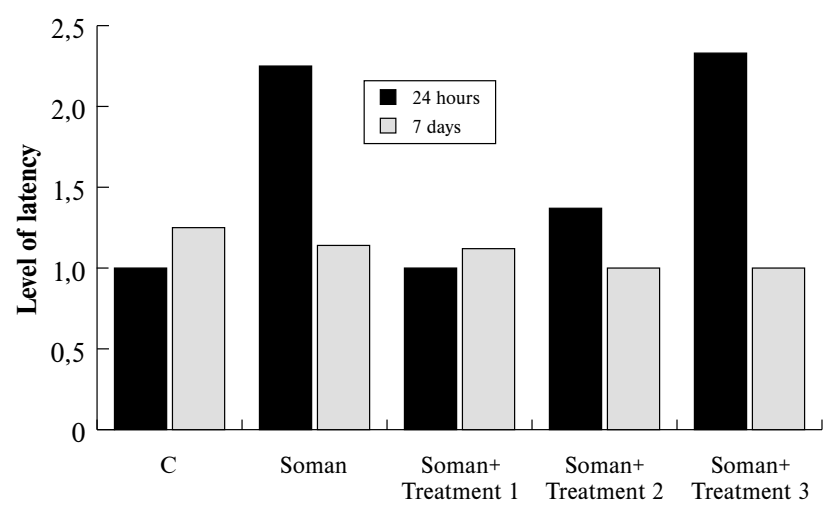

Fig. 3: The neuroprotective effect of antidotes on soman-induced decrease in forelimb and hindlimb grip strength at $24 \mathrm{~h}$ and $7 \mathrm{~d}$ following soman challenge. For symbols - see Fig. 1.

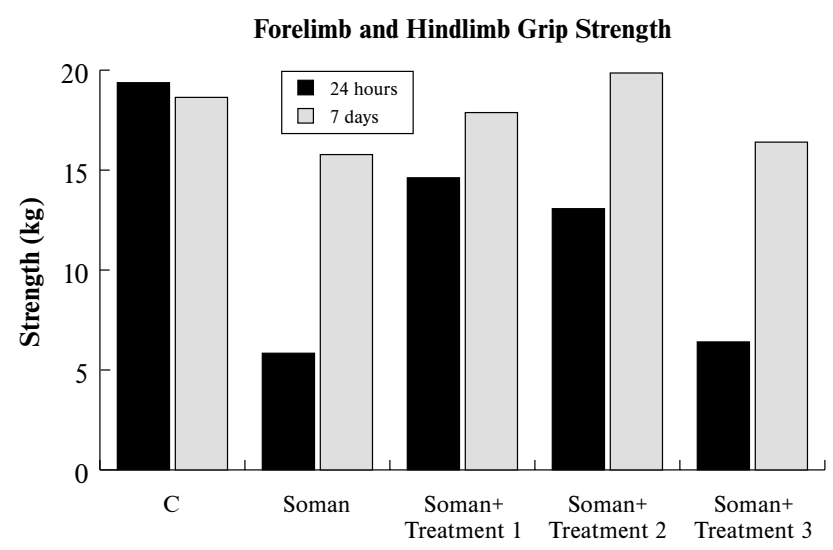

Fig. 4: The neuroprotective effect of antidotes on soman-induced decrease in horizontal motor activity at $24 \mathrm{~h}$ and $7 \mathrm{~d}$ following soman challenge. For symbols - see Fig. 1.

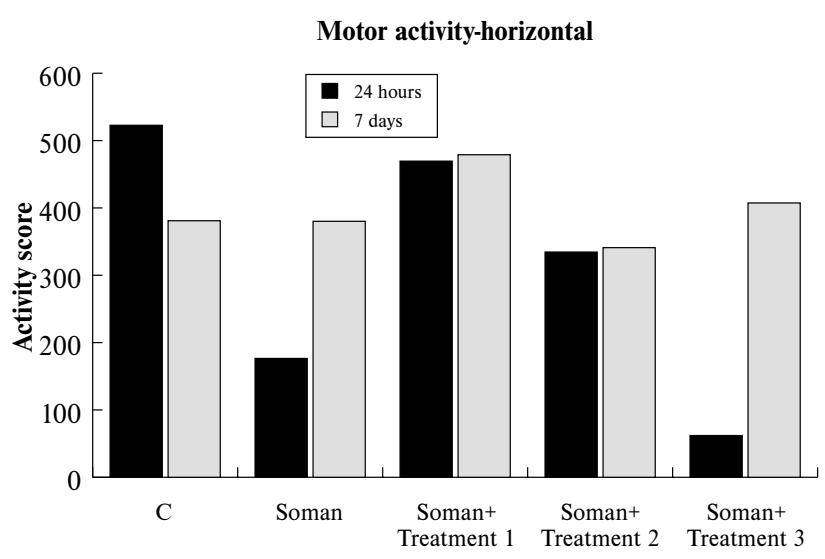

Fig. 5: The neuroprotective effect of antidotes on soman-induced decrease in vertical motor activity at $24 \mathrm{~h}$ and $7 \mathrm{~d}$ following soman challenge. For symbols - see Fig. 1.

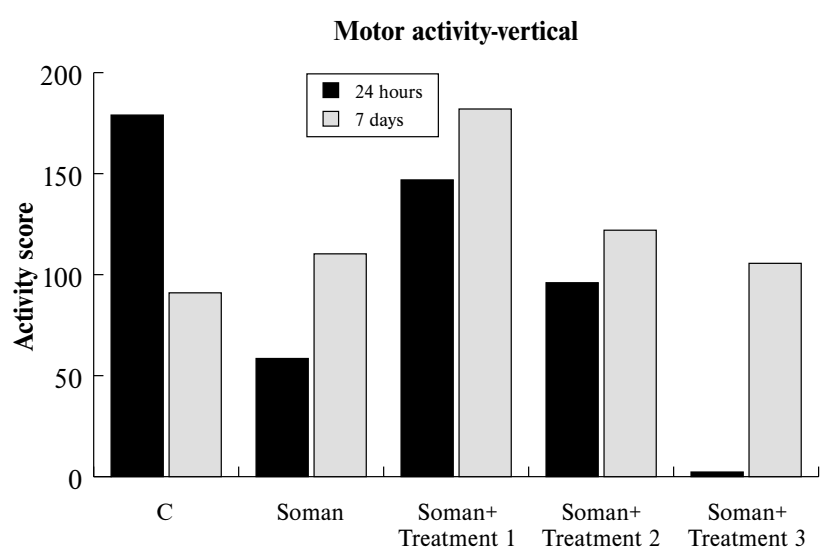

as vertical motor activity was markedly reduced at $24 \mathrm{~h}$ following soman injection (Figures 4,5). On the other hand, the above mentioned soman-induced neurotoxic symptoms were significantly diminished at $24 \mathrm{~h}$ as well as $7 \mathrm{~d}$ following soman poisoning when soman - poisoned rats were treated with atropine alone or with atropine in combination with the oxime HI-6 (Table 2, Figures 1-5).

\section{Discussion}

When soman-poisoned rats were treated with anticholinergic drug atropine, a relatively large decrease in neurotoxic symptoms induced by soman at a sublethal dose was observed. Atropine alone is able to antagonize the effects of $\mathrm{ACh}$ at muscarinic cholinergic receptor sites without changes of soman-induced inhibition of AChE activity $(16,23)$ and thus diminish neurotoxic effects of soman in the case of sublethal poisoning $(3,10)$. Nevertheless, atropine alone 
fails to prevent seizures and motor convulsions as well as mortality following exposure to soman at lethal and supralethal doses $(8,9,18)$.

When soman - poisoned rats were treated with atropine in combination with the oxime HI-6, a significant neuroprotective effect was demonstrated. This antidotal mixture seems to be effective in decreasing in the neurotoxicity of soman because of the beneficial effects of both antidotes (12). The oxime HI-6 is not only a relatively efficacious reactivator of soman-inhibited AChE, especially in the peripheral compartment (7), but it also has secondary antidotal effects that probably arise from its antimuscarinic, ganglion-blocking, postjunctional nondepolarizing action and effects on cardiovascular and respiratory systems (24).

On the other hand, another oxime obidoxime in combination with atropine is practically ineffective in the treatment of soman poisoning (8). In addition, our results confirm that obidoxime even diminishes the neuroprotective effect of atropine because our findings demonstrate the absence of any neuroprotective effect of this antidotal mixture in rats poisoned with the sublethal dose of soman.

In conclusion, atropine in combination with the oxime HI-6 is worth using in the antidotal treatment of soman poisoning for the elimination of soman-induced neurotoxicity. Atropine alone is also sufficient for the elimination of neurotoxic symptoms in rats poisoned with soman at sublethal doses but in the case of lethal soman poisoning the effect of atropine is not enough to allow poisoned experimental animals to survive at least $24 \mathrm{~h}$ following soman challenge $(9,25)$. The antidotal mixture that consists of obidoxime and atropine is not able to eliminate soman-induced neurotoxicity. Therefore, this antidotal mixture is not suitable for the treatment of soman acute poisoning even in the case of sublethal poisoning with nerve agents.

\section{Acknowledgements}

The authors would like to thank to Mrs. H. Antlová, Mrs. J. Petrová and Mrs. E. Reslová for their skilful technical assistance, to Dipl. Eng. J. Bielavský for synthesis of the oxime HI-6 and to Mgr. V. Bláha for the statistical evaluation.

\section{References}

1. Bajgar J. Present views on toxicodynamics of soman poisoning. Acta Med 1996;39:101-5.

2. Dawson RM. Review of oximes available for treatment of nerve agent poisoning. J Appl Toxicol 1994;14:317-31.
3. Fernando JC, Hoskins BH, Ho IK. A striatal serotonergic involvement of the behavioural effects of anticholinesterase organophosphates. Eur J Pharmacol 1984;98:129-32

4. Frantík E, Hornychová M. Clustering of neurobehavioral measured of toxicity. Homeostasis 1995;36:19-24.

5. Hornychová M, Frantík E, Kubát J, Formánek J. Neurotoxicity profile of supermethrin, a new pyrethroid insecticide. Cent. Eur J Publ Health 1995;3:210-8.

6. Kadar T, Cohen G, Sahar R, Ajkalay D, Shapira S. Long-term study of brain lesions following soman, in comparison to DFP and metrazol poisoning. Hum Exp Toxicol 1992;11: 517-23

7. Kassa J. Comparison of efficacy of two oximes (HI-6 and obidoxime) in soman poisoning in rats. Toxicology 1995;101:167-74.

8. Kassa J, Cabal J, Bajgar J, Szinicz L. The choice: HI-6, pralidoxime or obidoxime against nerve agents? ASA Newsletter 1997; 97-4:16-8.

9. Kassa J. A comparison of the therapeutic efficacy of conventional and modern oximes against supralethal doses of highly toxic organophosphates in mice. Acta Med (Hradec Králové) 1998;41: 19-21.

10. Kok A. REM sleep pathway and anticholinesterase intoxication: a mechanism for nerve agent-induced, central respiratory failure. Med Hypotheses 1993:41:141-9.

11. Koplovitz I, Romano JA, Stewart JR. Assessment of motor performance decrement following soman poisoning in mice. Drug Chem Toxicol 1989;12:221-35.

12. Koupilová M, Vachek J, Fusek J, Patočka J, Herink J. Neurotoxic effects of soman in animal experimental poisoning and the influence of therapy. Homeostasis 1996;37:266.

13. Lallement G, Clarencon D, Bronchier G, Baubichon D, Galonnier M, Blanchet G, Mestries J-C. Efficacy of atropine/pralidoxime/diazepam or atropine/HI6/prodiazepam in primates intoxicated by soman. Pharmacol Biochem Behav 1997;56: 325-32.

14. Leadbeater L, Inns RH, Rylands JM. Treatment of poisoning by soman. Fundam Appl Toxicol 1985;5:S225-31.

15. Lemercier G, Carpentier P, Sentenac-Roumanou H, Morelis P. Histological and biochemical changes in the central nervous system of the rat poisoned by an irreversible anticholinesterase organophosphorus compound. Acta Neuropathol 1983;61:123-9.

16. Marrs TC. Organophosphate poisoning. Pharmacol Ther 1993;58:51-66.

17. McDonough JHJr, Smith RF, Smith CD. Behavioral correlates of soman-induced neuropathology: Deficits in DRL acquisition. Neurobehav Toxicol Teratol 1986;8:179-87.

18. McDonough JHJr, Shih T-M. Neuropharmacological mechanisms of nerve agentinduced seizure and neuropathology. Neurosci Biobehav Rev 1997;21:559-79.

19. Moser VC, Tilson H, McPhail RC et al. The IPCS collaborative study on neurobehavioral screening methods: II. Protocol design and testing procedures. Neurotoxicology 1997;18:929-38.

20. Petras JM. Neurology and neuropathology of soman-induced brain injury: an overview. J Exp Anal Behav 1994;61:319-29.

21. Sidell FR. Clinical considerations in nerve agent intoxication. In: Somani SM, ed. Chemical Warfare Agents. New York: Academic Press, 1992; p. 335.

22. Slechta DA. Behavioral measures of neurotoxicity. Neurotoxicology 1989;10:271-96

23. Taylor P. Anticholinesterase agents. In: Hardman JG, Limbird LE, eds. The Pharmacological Basis of Therapeutics (9th ed.). New York: Macmillan, 1996; p. 129

24. van Helden HPM, Busker RW, Melchers BPC, Bruijnzeel PLB. Pharmacological effects of oximes: how relevant are they? Arch Toxicol 1996;70:779-86.

25. Worek F, Szinicz L. Atropine and oxime treatment in lethal soman poisoning of anaesthetized guinea-pigs: HLö 7 dimethansulfonate versus HI-6 dichloride. Pharmacol Toxicol 1993;72:13-21.

Accepted April 1999.

Submitted September 1999.

Doc. MUDr. Jiř́i Kassa, CSc., P.O. Box 35/T, VLA JEP, 50001 Hradec Králové, Czech Republic. e-mail: kassa@pmfhk.cz 